\title{
Factors Influencing Development of Farm Forestry in Lugari District, Kakamega County, Western Kenya.
}

\author{
Otsieno Fredrick Sikuku ${ }^{1}$, Musa Gweya Apudo ${ }^{2}$ and Gilbert O. Ototo ${ }^{3}$. \\ ${ }^{1}$ Kenya Forestry College, Londiani, Kenya $;{ }^{2}$ School of Natural Resource and Environmental Management, \\ University of Kabianga, P.O. Box 2030 - 20200, Kericho, Kenya ${ }^{3}$ School of Natural Resource Management, \\ University of Eldoret, Kenya. \\ Corresponding author, E-mail: musaapudo@yahoo.com
}

\begin{abstract}
This study was conducted to establish the factors influencing the development of farm forestry in Lugari Division, Western Kenya. Data was collected between December 2007 to January 2008. Structured questionnaires/schedules, key informant interviewing, and secondary sources of data were used to collect data. All collected data were entered in SPSS 13.5 to facilitate statistical analysis using descriptive statistics such as frequency distributions and cross tabulations. Significant differences between expected and observed attributes were analyzed by non-parametric Chi-square tests.

Farm sizes, species preferences, end use of tree products, access to and availability of preferred germplasm and planting materials, availability of resources for raising seedlings, access to extension services, and marketing constraints as well as biological and technical factors such as diseases, pests and planting methodologies were established as important factors influencing farm forestry and tree planting in general, in the division.

This study has also demonstrated that farm forestry can be a useful tool for enhancing the livelihoods of many people and contributing to rural development in Lugari, and can be readily adopted if identified challenges can be comprehensively addressed.

It is recommended that tree propagation techniques and distribution networks should be developed to enable affordable access to a wide range of appropriate germplasm. Small scale farmers should be assisted, through extension services, to manage and enhance the value of their tree crops.

Institutional support through incentives such as credits, subsidies, technical support and creation of market opportunities including forest policy and legislation sensitization and implementation would boost farm forestry activities in Lugari.

Key words: Farm Forestry; Livelihoods; Rural development; Lugari District
\end{abstract}

\section{Introduction}

Farm forestry has been defined as the practice of growing trees on privately owned agricultural land for household use and for sale to local users (FAO, 1990). Farm forestry encompasses growing of trees in farmlands and involves village woodlots and communal forests (Taylor and Mehl, 1985). Negi (1986) describes it as part of social forestry involving the practice of forestry outside the conventional forests for the benefit of both rural and urban communities.

Currently farm forestry in Kenya is taking place as a way of improving the earnings of the farmers. As such, many farmers who are currently earning more from agriculture are still reluctant to put their farms for growing trees.

Farm forestry management in Kenya has evolved over the years from traditional setups characterized by earlier stages of clearing trees to create room for agricultural activities to later reversal stages of tree planting during the colonial and post-colonial periods. It has involved species adoption, preferences, site selection, planting patterns, species mix, density, management intensity, specialized production systems, utilization, markets and marketing (Cheboiwo, 2004).

The practice has moved from common resource extraction to planting in compounds, boundaries and as windbreaks, inter-cropping and lately intensively managed mono cropping in the form of woodlots for commercial purposes (Koech et al., 2005). The commercial aspect has shaped regional dominance of some species in the country, vis-à-vis, Grevillea robusta and Cupressus lusitanica in Central Kenya; Casuarina equisetifolia in the Coastal strip and Acacia mearnsii and Eucalyptus spp in Western Kenya.

The potential of farm forestry is crucial in the current context whereby no more land can be allocated to indigenous forests and to industrial plantations in order to meet the forest production output desired to spur national development. Kenya's forest policy recognizes the importance of farm forestry in reducing pressure on indigenous forests. It recognizes the role of farm forestry in diversifying farm production as well as providing subsistence and incomes through products such as timber/fuel wood and fodder in addition to its contribution to soil and water conservation (GoK, 2005). 
This paper focuses on the factors influencing the development of farm forestry in Lugari Division, of Lugari District, Kakamega County, Western Kenya.

\section{Location of the study area}

\section{Materials And Methods}

Lugari Division is situated in the central part of Lugari District in Western Province of Kenya (Figure 1). The division is situated about $350 \mathrm{~km}$ North-West of Nairobi. It lies at an average altitude of between 1600 $1999 \mathrm{~m}$ above sea level.

\section{Climate and hydrology}

Lugari Division has temperatures varying from $8.8-28^{\circ} \mathrm{C}$ within the year. Maximum temperature varies over the year between $22-28^{\circ} \mathrm{C}$ while minimum temperature range between $12-16^{\circ} \mathrm{C}$. Rainfall pattern is bimodal; the mean being just over $1100 \mathrm{~mm}$ annually with the long rains falling between the months of April and June, short rains fall between August and November while December to February are dry months.

\section{Geology and soils}

The Lugari bedrock is composed largely of soft volcanic ashes and turfs with only rare outcrops of agglomerates and lavas. The soils are fertile and well drained, ranging from dark brown sandy loam to red oxisols.

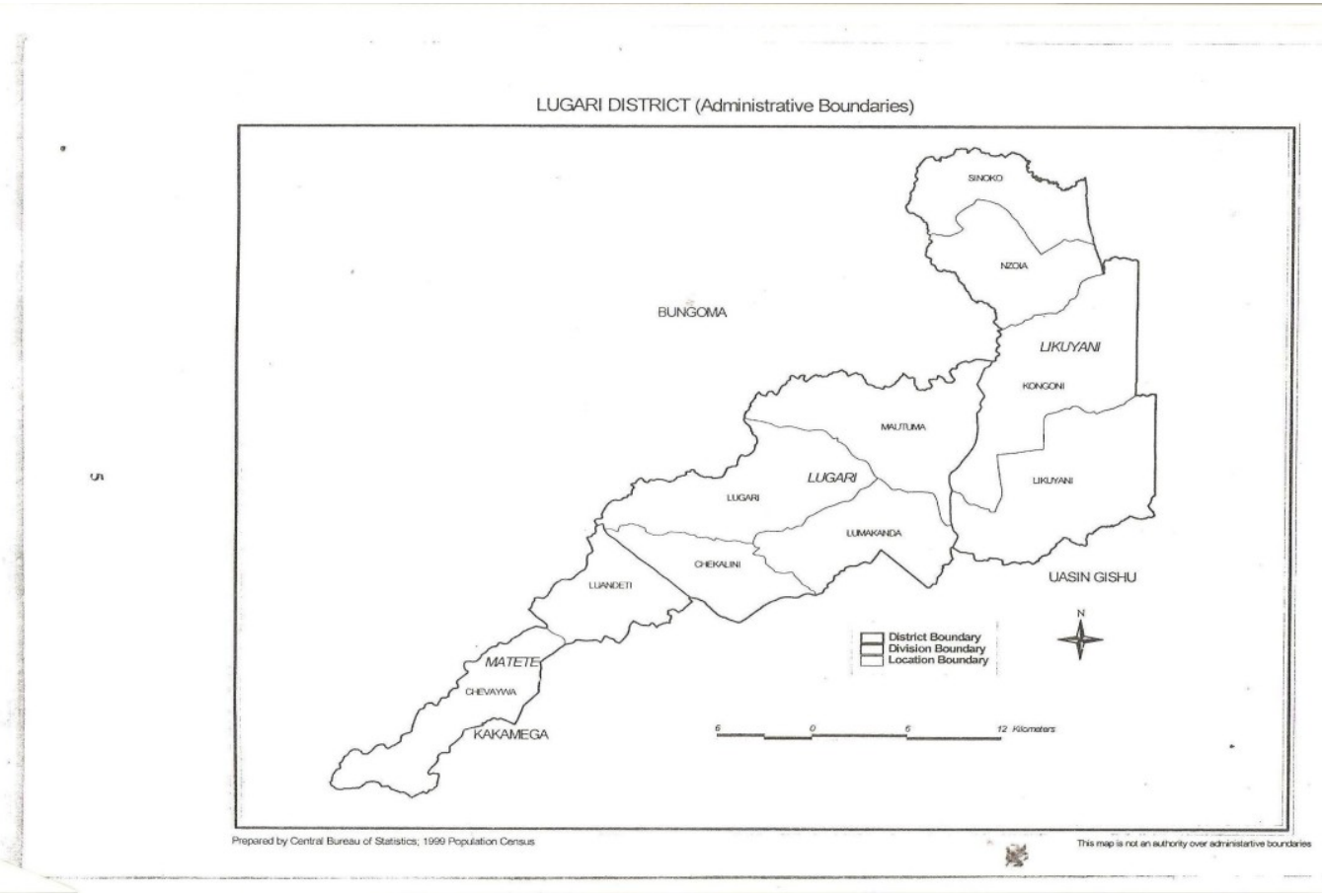

Figure 1: Map of Lugari District showing the position of Lugari Division

\section{Population and land tenure}

The area had slightly over 106,160 persons by the year 1999 with a density of about 90 persons per square kilometer though no recent census has been conducted within the area (GoK, 2001). The number of households was approximately 18,500. Land tenure is exclusively individual freehold ownership.

\section{Economic activities}

The main economic activities within the study area are agriculture through crop and livestock production. Other land use activities include agro-forestry and forestry.

\section{Research design and sampling procedure.}

Both qualitative and quantitative data were gathered from households across the division. Crosssectional survey design was used in this study to investigate households that adopted farm forestry.

This study relied on a combination of random sampling and purposive sampling techniques to select the farmers to be included in the sample. The purposive sampling technique identified subgroups in the population that had 
the requisite information to be included in the study. The farmers who practiced farm forestry in each location were identified through a reconnaissance survey. Sampling then proceeded from this population.

\section{Data collection.}

The researcher administered questionnaire was the main instrument of data collection used.

Data was collected between December 2007 and January 2008. The survey was conducted using semi-structured questionnaire and direct observations.

\section{Data Analysis and presentation}

Analysis of data was done statistically using SPSS 13.5 statistical package. Qualitative methods of data analysis employing descriptive statistics were used to explain the results. All results were accepted as significant at $\alpha=0.05$. The data were presented in a synthesized form using graphical techniques such as tables, bar graphs and pie charts.

\section{Socio-economic background of the respondents}

\section{Results}

The socio-economic backgrounds of the respondents considered in this study were: age, gender, educational background and occupation. The mean age of the respondents in the study area was $47.1 \pm 1.47$ years. There were no significant differences in the mean ages of the sampled members across the locations.

A significantly higher numbers of males than females in the division were sampled during this study. Gender distribution was similar in all the sample locations.

Significant differences were established relative to levels of education. Those without basic education were few (6.7\%). The proportion with university level of education was similar to those without education. Those with primary level of education were about one fifth of the total population. Holders of secondary school certificate of education were the most in the area.

\section{Relationships between farm size and land under trees}

There were no significant differences in average farm sizes across the locations. The farm sizes were uniform for most of the farmers sampled. Likewise, there were no significant differences in the areas of the farms under trees in all the locations. The farmers were actually planting only about $9 \%$ of their farms with trees (Table 1).

Table 1: The actual land size, land under trees and percentage of land size farmers have planted trees across the locations

\begin{tabular}{|l|c|}
\hline \hline & Mean land size (acres) \\
\hline Farm size & $4.32 \pm 0.61$ \\
\hline Acreage under trees & $0.38 \pm 0.08$ \\
\hline Percentage of acreage under tree & $8.79 \pm 1.22$ \\
\hline
\end{tabular}

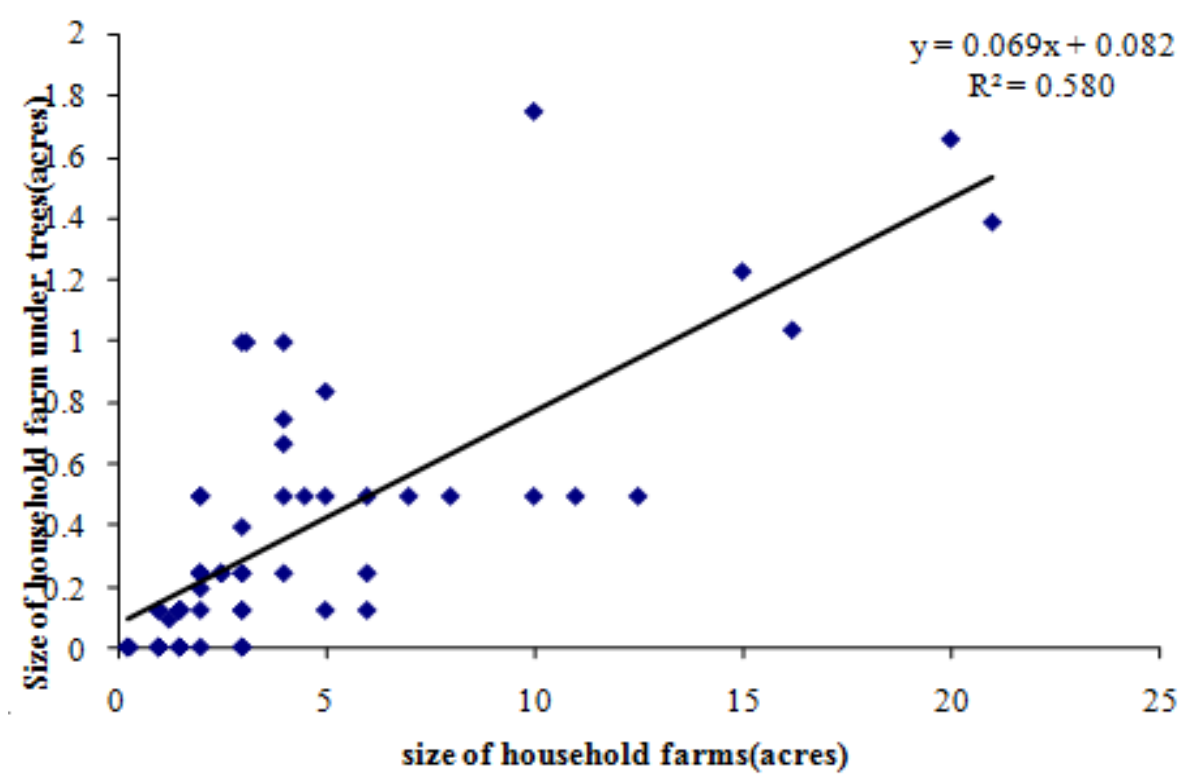

Figure 2: The relationships between the total land size and area of farm under trees 
Figure 2 is a linear regression model showing the relationships between size of household farms and acreage that farmers have set aside for tree planting. There was a significant positive correlation between the farm size and area of the farms under trees.

\section{Tree species grown by farmers}

About $91 \%$ of the farmers interviewed grew trees in one configuration or the other. The trees grown were of different types, indigenous or exotic, for a variety of purposes.

Out of 29 indigenous species identified across the farms a significantly higher number of farmers $(35 \%)$ were planting Markhamia lutea. This was followed by Spathodea nilotica (33.3\%) and Croton macrostachyus (18.3\%), (Figure 3).

The type of tree species preferred was dependent on the location. Grevillea robusta was planted more by farmers in Mautuma. Spathodea nilotica was planted more by farmers in Lumakanda. Eucalyptus spp. was planted most by farmers in Lumakanda and Mautuma locations.

Among the exotic species most preferred by farmers were Cupressus lusitanica and Grevillea robusta in (85\%) and $(83 \%)$ of the farms respectively, followed by Pinus patula and Jacaranda mimosifolia in $30 \%$ of the farms for each. Fewer farmers (28\%) grew Eucalyptus saligna (Figure 4).

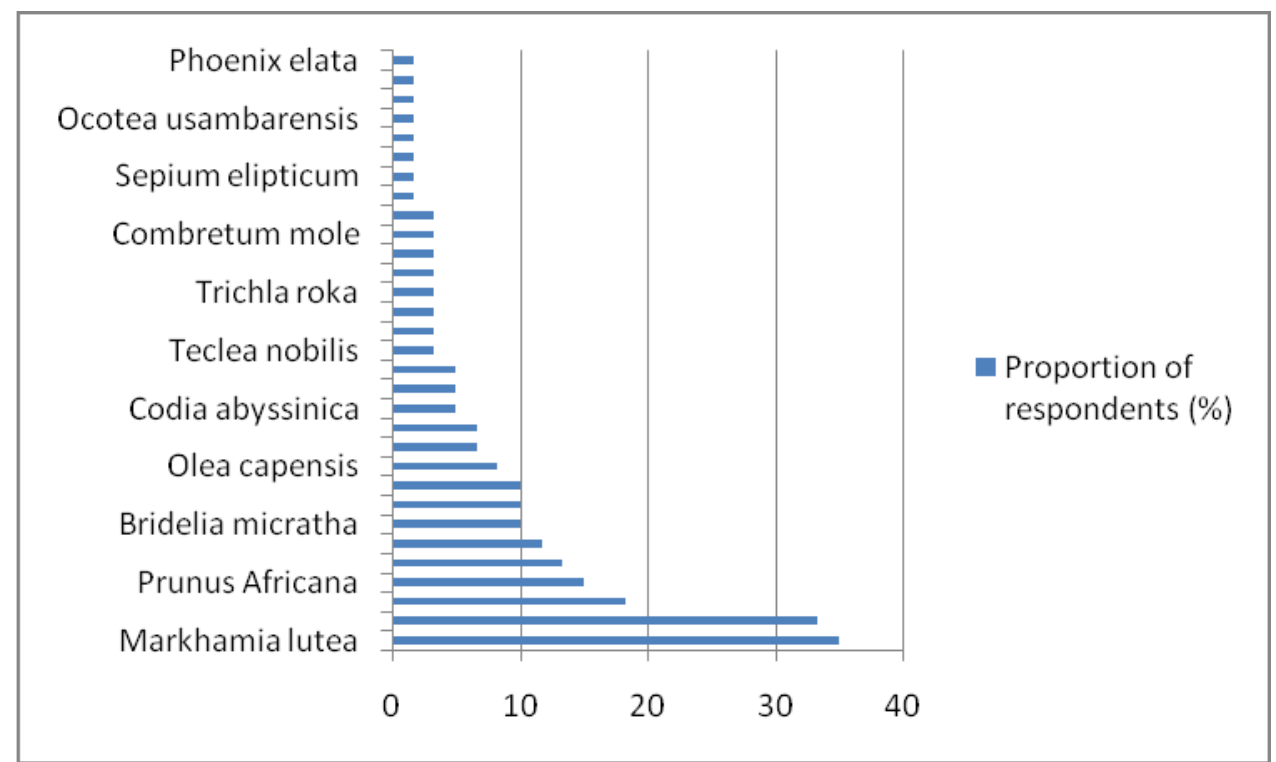

Figure 3: Indigenous tree species preferences

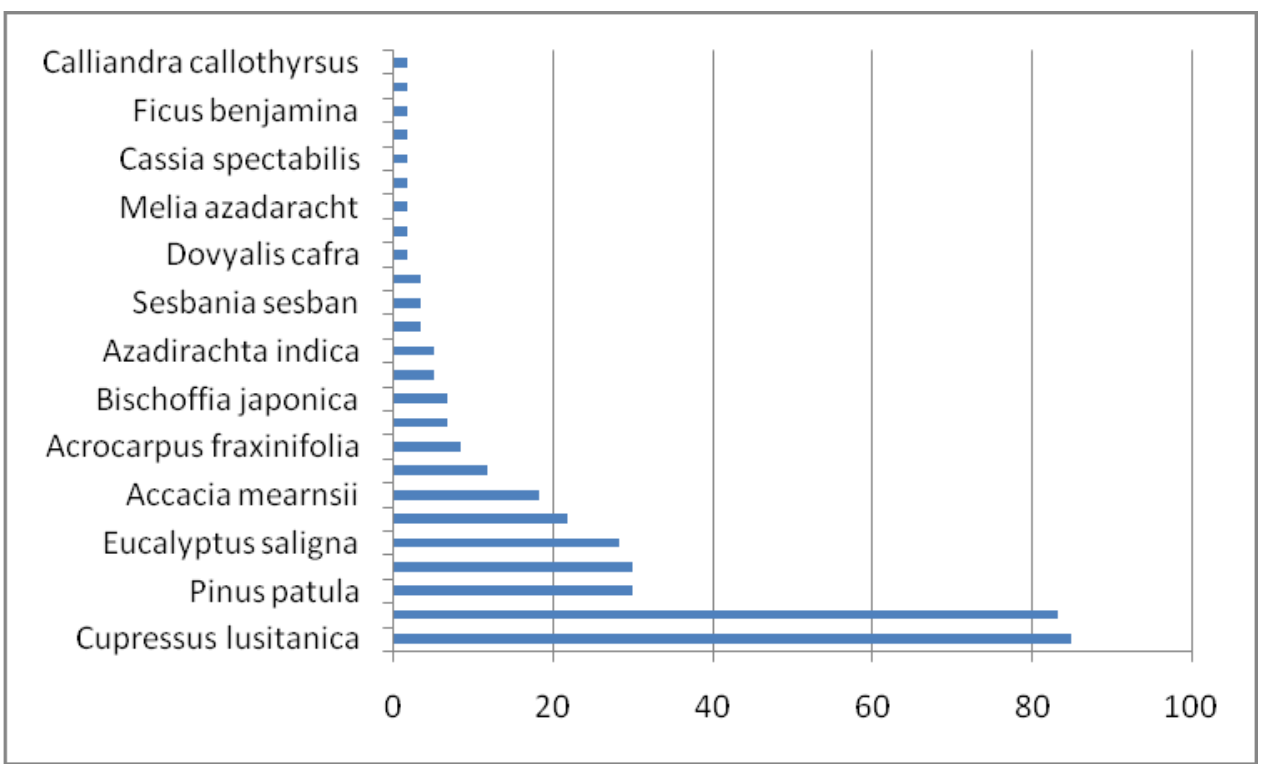

Figure 4: Preference for exotic tree species (\% of farms growing the species) 


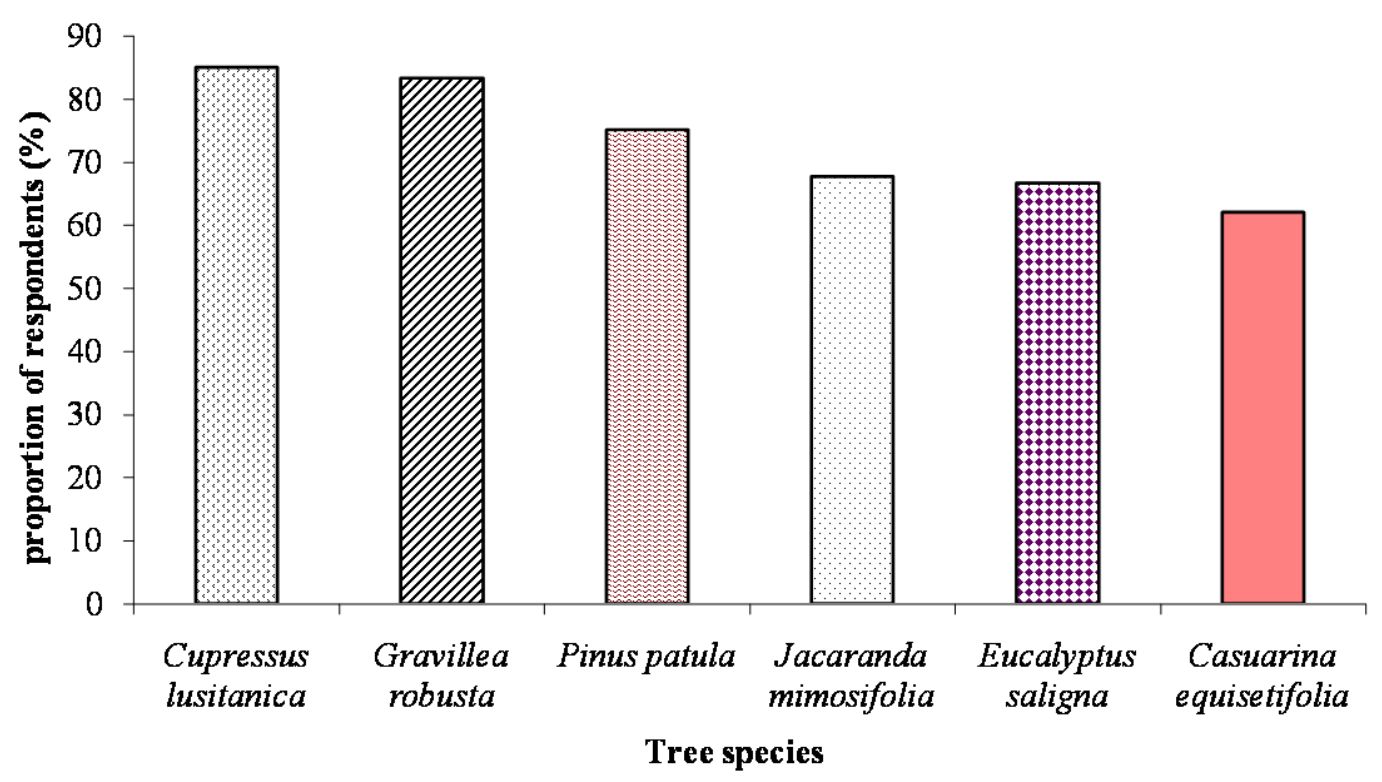

Figure 5: Six tree species most preferred by farmers in Lugari Division

The six most preferred tree species by farmers are shown in Figure 5. These species were each preferred by more than $60 \%$ of the respondents.

\section{Utilization of the trees grown on farms}

Main uses of trees were identified as follows: firewood (96.7\%), poles (86.7\%), shade (86.7\%) and windbreak (73.3\%).

\section{Existing challenges of tree planting}

Results indicated that only $16.7 \%$ of farmers had nurseries in their farms while the remaining $83.3 \%$ bought their seedlings from other nurseries including from the Kenya Forest Service. The seed supply was inadequate for $55 \%$ of the people, with only $45 \%$ attesting that the seed supply was adequate. The farmers who were able to purchase seeds from the Kenya Forest Services cited the cost of the seeds as a major challenge. Over ninety one percent $(91.7 \%)$ cited shortage of labour as a major hindrance to the growth and development of farm forests.

About $60 \%$ cited lack of water as another problem that affected the development of farm forests.

Lack of extension services was also cited by majority of farmers (72.1\%) as another challenge to development of farm forestry.

The key challenges in the marketing of farm and farm forestry produce are as shown in Figure 6. For majority of farmers, low pricing was the major marketing constraint followed by lack of transport and lack of market for their produce.

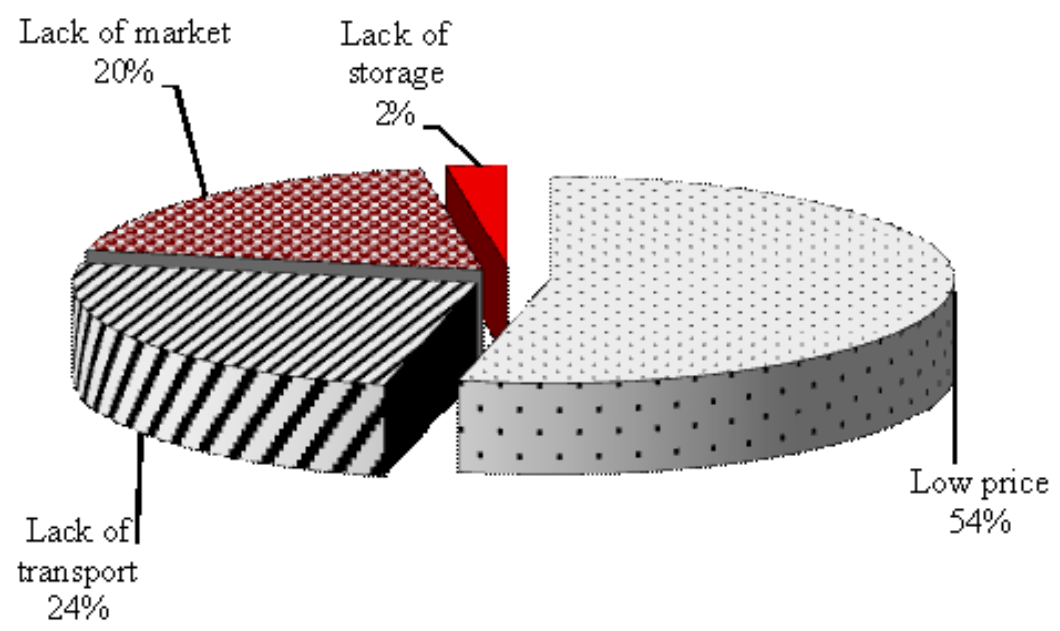

Figure 6: Main challenges in marketing of the forest products 
There were attempts to obtain information from the farmers' concerning the kind of problems that affected their trees and seedlings. The results of kinds of problems affecting the trees among the farmers are shown in Figure 7.

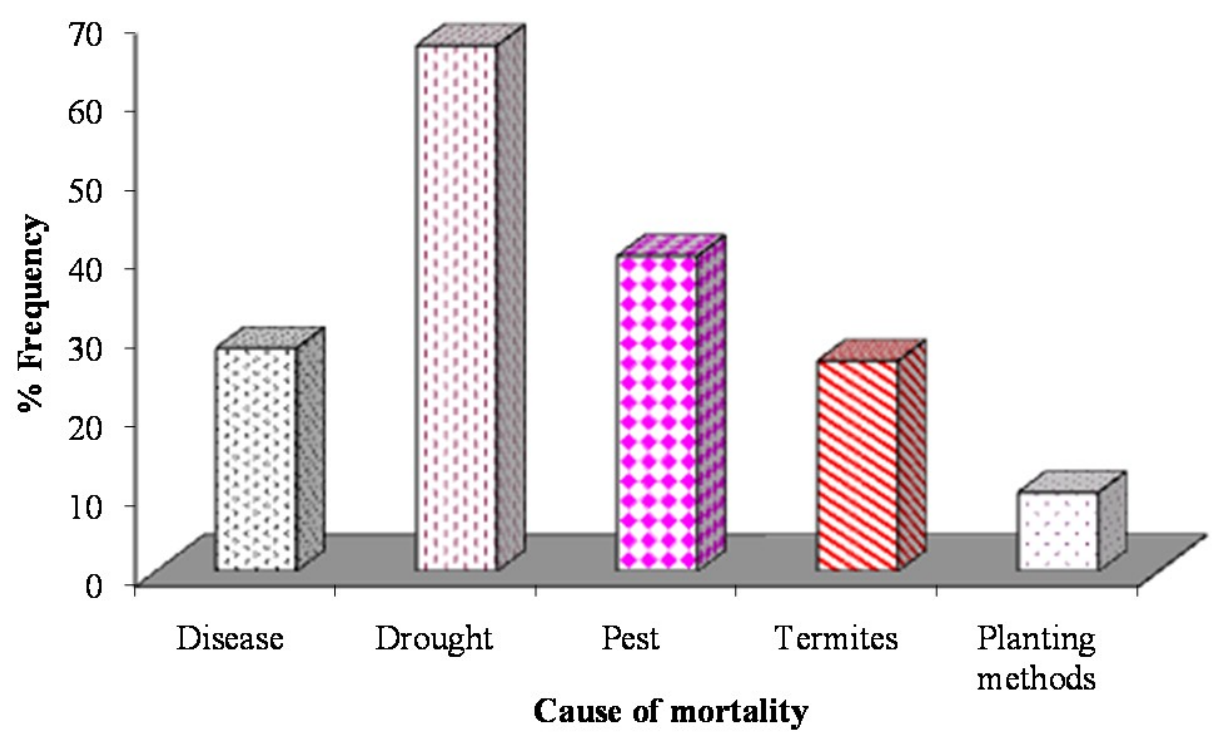

Figure 7: Causes of tree mortality in the farms

\section{Discussion}

\section{Influence of land size on the growing of tree species in the farms}

Land is one of the most important resources in Kenya (Kinyanjui, 2005). Many farmers still prefer agriculture for food production over growing of trees and are therefore less willing to avail much land for forestry purposes. In forestry, it is widely thought that land size can influence the type and number of trees to be planted within a given unit area. In Lugari, farm sizes within the study area were relatively small. Small land size has been a challenge in adoption of improved farm forestry practices especially in areas where the population density is high and the land sizes are small. In the present study farm trees occupied less than $10 \%$ of the overall farm size. There were also no significant variations in the land sizes among the locations, which would imply that opportunities for planting of trees are not expected to differ widely among the farmers across the locations.

When land size increases, the potential for production and diversification of farm forestry products are also expected to increase (Ogendo, 1987). In Kenya, much of the land is reserved for subsistence food crops production and other small sizes left for dairy production. In this study it was apparent that as farm size increased, many farmers used increasing areas of their lands for growing of trees. The willingness by farmers to practice Farm forestry could be an indicator that farmers recognize and are beginning to realize the benefits of Farm forestry to their livelihoods.

Though farmers were more willing to devote much of their land for tree growing as a function of the increasing land size, the role of the Kenya Forest Service in promoting tree growing should also be recognized at this point. Ogweno (2001) had earlier established elsewhere in Uasin Gishu that farmers receiving support planted more trees in their farms more voluntarily and thus resulted to increased farm production of trees in the area. This therefore points to the relative importance of farmers' support rather than land size to grow trees.

\section{Tree species adopted for farm forestry}

Farmers in Kenya grow a great variety of tree species (Foley and Bernard, 1984; Jama et al., 1998a; Argwing-Kodhek et al., 1999; Dewolf and Rommelse, 2000; Evans, 2007) consistent with findings from the present study. The most commonly planted indigenous tree species were Markhamia lutea, Spathodea nilotica, Croton megalocarpus while the most planted exotic species were Cupressus lusitanica, Eucalyptus saligna and Grevillea robusta. The most preferred exotic tree species were Eucalyptus saligna (60-75\% of the farmers), Cupressus lusitanica (67 - 75\% of the farmers) and Grevillea robusta (30 - 40\% of the farmers).

During an earlier survey of 1999 elsewhere, farmer preference for various tree species was investigated. (Pisanelli et al. 2000). Crotalaria grahamiana, Tephrosia candida, Eucalyptus saligna and Sesbania sesban, 
received highest ranking from farmers, closely followed by Tephrosia vogelii. The farmers' explanation for these scores related to the good impact on soil and crop production under Sesbania sesban, Crotalaria grahamiana and Tephrosia candida (in that order).

In the present study, many farmers prefered Cupressus lusitanica, Grevillea robusta, Pinus patula, Jacaranda mimosifolia, Eucalyptus saligna and Casuarina equisetifolia. The main reasons are socio-economic and silvics apart from efforts by extension service providers. E. saligna, C. lusitanica and G. robusta are fast growing species and were targeted for cash, fuel wood and timber (Ogweno et al. 2001). Furthermore, seeds from these species are cheap and readily available even through local collection.

\section{Utilization of farm forestry trees}

Earlier studies outside Lugari indicate that farmers preferred exotic tree species (Cupressus lusitanica, Grevillea robusta and Eucalyptus spp) due to their commercial value. Presently, majority of the farmers use tree species grown on farms for firewood, poles, shade and windbreak. The utilization of tree species for firewood and other uses seemed to be linked to the ease of availability of these products. For instance only three species were used for timber. Four species were used for firewood, and poles. Most of the species of trees were used for making charcoal and as boundary markers in the farms, and for provision of shade. Likewise, more farmers were using Eucalyptus saligna for firewood, charcoal, poles and timber. G. robusta was used more for reinforcement of boundaries. S.nilotica was more useful in provision of shade while Persea americana provided fruits.

Framers recognize the commercial value of trees and as such target specific species (Eucalyptus spp., Cupressus spp and Grevillea robusta) to be raised for cash.

\section{Constraints facing development of farm forestry in Lugari}

Constraints facing farm forestry in Lugari were numerous. Among those who lacked nurseries in their farms were purchasing tree seeds and seedlings from the Kenya Forest Service. The seed supply however, was inadequate. The farmers who were able to purchase seedlings from the Kenya Forest Service cited the cost of the seedlings as a major hindrance to acquisition of the seedlings.

Other problems included lack of labour and reliable water supply. Earlier studies by Ogweno et al. (2001) reported that the main constraints to farm forestry nursery development is lack of funds for the purchase of potting materials, tools and equipment (mainly watering cans, wheelbarrows and other farm tools), pests and diseases, and livestock damage.

Farm size often limits the area that can effectively be used to raise farm forests. Most crops that would be preferred are those that yield quick returns and take shorter time to grow. Crops such as maize, beans, potatoes and other subsistence crops will be preferred to tree crops. Other constraints facing farmers were inadequate extension services.

Marketing constraints affecting the farmers were mainly lack of information on appropriate markets, lack of storage and transport as well as low pricing dynamics. Lack of market information within the area was directly related to the small-scale nature of practices that these farmers were involved in. In areas where majority of farmers are small scale, they tend to rely on informal advice or information from other farmers who also have limited knowledge about the market (Johnsons, et al., 2001). Perishable farm products such as fruits require processing before marketing to minimize spoilage and wastage. Absence of appropriate information on processing as well as facilities means that these farmers cannot process their products before marketing. Inadequate information on processing made products destined for the market to be of low quality. Financial limitations made it impossible to secure the right equipment to use in processing and as such overall benefits from the farm forestry practices were low. Marketing organizations for farm forestry products were also not available and as such farmers could not get information on pricing and credit financing for farm forest products. Finally one of the key challenges facing farm forestry practices in Lugari were the biophysical problems that affect the establishment and growth of the trees planted on the farms. In this area, drought, pests and diseases that affect trees grown were reported by farmers to limit their production of trees from the farms. Drought/moisture stress exposed trees to attacked by pests and diseases.

\section{Conclusion}

Farmers in Lugari have relatively small farms of average size 4 acres and less than $10 \%$ of the land is utilized for farm forestry. Farmers were planting more trees in their farms as the land size increased.

Farmers in Lugari planted both indigenous tree species as well as exotics species in various niches for a variety of purposes. The most preferred tree species by farmers were, however, for cash income, improvement of soil fertility and fodder. Fruit trees, live fence species and medicinal plants also had preference among farmers.

The major constraint facing farmers attempting to adopt farm forestry practices ranged from insufficient tree nursery networks in the farms, availability and affordability of seeds and seedlings, access to water, inadequate 
extension services, marketing constraints to biological and technical factors such as diseases, pests and planting techniques of the tree species.

\section{Recommendations}

Findings from this study have highlighted the importance of farm forestry benefits in encouraging the farmers in rural areas to increase tree production. We make the following recommendations:

1. State agents in conjunction with other extension agencies should step up extension services and include distribution of tree seedlings to any willing farmer at locally affordable costs to encourage farm forestry.

2. These results show that many tree species do well in Lugari and therefore extension agencies should educate farmers on how to manage the many tree species as an option for soil fertility management and for wood (commercial and subsistence) and fodder production.

3. This study has shown that even small scale farmers allocate some of their land for tree growing. It is recommended that extension agents assist them in managing the wood lots for maximum wood production and hence maximum returns.

4. Institutional support through incentives such as credits, subsidies, technical support and creation of market opportunities would boost the production of tree seedlings by the local farmers and effect farm forestry development.

\section{References}

[1]. Argwings-Kodhek, G., T. Jayne, G, Nyambane, T. Awuor, and T. Yamano. (1999). How can micro-level household information make a difference for agricultural policy making?

[2]. Cheboiwo, J. K. (2004). Economic and Non-Economic Determinants of Farm Forestry Development in Western Kenya: A Case of Uasin Gishu and Vihiga. D. Phil. Thesis, Moi University, Kenya.

[3]. Dewolf, J. and R. Rommelse. (2000). Improved fallow technology in western Kenya: Potential and reception by farmers. Unpublished Mimeo

[4]. Evans J. (2007). Overview of tree planting on small farms in the tropics. Proceedings of an international workshop held in Nov 25 1987 in Pattya, Thailand

[5]. FAO (1990). Forestry resource assessment reports.

[6]. Foley, G. and Barnard, G. (1984). Farm and community forestry. International Institute for environment and development.

[7]. GoK. (2001). Population and House Census. Republic of Kenya, Ministry of Planning and National Development, Central Bureau of Statistics. Nairobi Kenya.

[8]. GoK (2005) Forest Policy. Government Printer, Nairobi. Kenya.

[9]. Johnsons, N., Andy, W. and Daniel. P. (2001). Developing marketing for the forest products: Issues and lessons for innovators.

[10]. Kinyanjui, M.J. (2005). Gender barrier to land conservation in Kuresoi Location, Kericho District. J. Hum. Ecol. 8: 41-50.

[11]. Koech, E., Hitimana, J., Cheboiwo., J., Misonge, J. and Mureithi, W. (2005). The role of farm forestry in socio-economic development and environmental conservation in Kenya: Challenges and opportunities.

[12]. Kothari, C.R. (2005). Research methodology: Methods and techniques. Daryaganj, New Delhi: New Age International (P) Ltd.

[13]. Negi, S.S. (1986). A handbook of social forestry. International book distributors.

[14]. Ogendo, H. W. (1987). Tenure of Trees or Tenure of Lands. In: Raintree, J.B. (ed). Proceedings of an International workshop on Tenure Issues in Agroforestry, Land and Tenure Centre, Madison, Wisconsin, USA and ICRAF, Nairobi, Kenya, pp 225-230.

[15]. Ogweno, D.O., Imo, M., Matano, A. and Orinda, B. (2001). Evaluation of the management and sustainability of private tree nurseries in Kipkaren river catchment, Kenya. 1st National Scientific Conference, Lake Victoria Environmental Management Project, Kisumu, Kenya. 15th - 19th October, 2001.

[16]. Pisanelli, A., Franzel S., DeWolf J., Rommelse R., and Poole J. (2000). Adoption of improved tree tree species in Western Kenya: Farmer practices, knowledge and perception. International Centre for Research in Agroforestry: Nairobi, Kenya. 